\title{
PENGARUH PENAMBAHAN RESIN TERHADAP RESISTIVITAS DAN POROSITAS CAMPURAN PASIR- SEMEN
}

\author{
Ardian Putra, Irpan Suhadi \\ Laboratorium Fisika Bumi, Jurusan Fisika, FMIPA Universitas Andalas \\ Kampus Unand Limau Manis, 25163, Padang, Sumatera Barat \\ email: ardhee@fmipa.unand.ac.id
}

\begin{abstract}
ABSTRAK
Telah dilakukan penelitian tentang pengaruh penambahan resin terhadap resistivitas dan porositas campuran pasir-semen. Bahan yang digunakan adalah pasir (butiran pasir), semen Padang Portland tipe 1 dan resin damar. Sampel dibuat dengan komposisi massa pasir 20 gr, 40 gr, 60 gr, 80 gr, massa resin 0 gr, 10 gr, 20 gr, 30 gr, 40 gr, dan massa semen 60 gr. Resistivitas terbesar didapatkan sebesar $0,040 \Omega \mathrm{m}$ pada campuran dengan massa pasir 60 gr dan massa resin 0 gr, resistivitas terkecil $0,020 \Omega \mathrm{m}$ pada campuran dengan massa pasir 80 gr dan massa resin 40 gr. Hasil yang diperoleh memperlihatkan resistivitas turun dengan penambahan massa resin dan tidak memperlihatkan pola yang baik dengan penambahan massa pasir. Porositas terbesar adalah $69 \%$ pada campuran dengan massa pasir 20 gr dan massa resin $20 \mathrm{gr}$, porositas terkecil adalah $27 \%$ pada campuran dengan massa pasir 60 gr dan massa resin 0 gr. Porositas turun dengan penambahan massa pasir, namun porositas naik dengan penambahan massa resin 0-20 gr, dan turun atau konstan dengan massa resin 20-40 gr. Nilai resistivitas menurun dengan penambahan nilai porositas, namun diperlukan data yang lebih banyak untuk menguatkan hubungan ini.
\end{abstract}

kata kunci : porositas, resin, resistivitas

\section{PENDAHULUAN}

Penelitian sering dilakukan dengan menyelidiki sifat mekanik dari semen-tanah, sedangkan sifat dari resistivitas listrik tidak ditangani dengan baik. Dalam tulisan ini, sifat dari resistivitas listrik dari semen-tanah dibentuk kembali dan diselidiki. Hasil pengujian Liu, dkk, (2008) menunjukkan bahwa tahanan listrik tanah-semen naik dengan meningkatnya rasio campuran semen dan waktu pemeraman, sedangkan menurun dengan peningkatan kadar air, derajat kejenuhan dan rasio campuran air semen. Sebuah persamaan sederhana diberikan untuk memprediksi tahanan listrik tanah-semen di bawah kondisi waktu curing tertentu dan rasio air-semen. Hal ini menunjukkan bahwa tahanan listrik memiliki nilai sebanding dengan kuat tekan (elastisitas). Putra, dkk (2010) melakukan pengujian resistivitas campuran antara semen dan resin dengan konsentrasi resin $10 \mathrm{ml}, 40 \mathrm{ml}$, dan $60 \mathrm{ml}$. Resistivitas sampel campuran dengan nilai rasio air terhadap semen yang tetap dan diuji menggunakan Nanuira Resistivitymeter NRD 22T memperlihatkan kenaikan nilai resistivitas terhadap peningkatan volume resin yang berada dalam campuran semen. Penelitian mengenai pembuatan mortar dengan penambahan serbuk gergaji kayu jati untuk memperlihatkan adanya pengaruh terhadap kuat tekan, kuat tarik dan daya serap air dan ada perbedaan kuat tekan, kuat tarik maupun daya serap air karena adanya penambahan serbuk gergaji kayu jati (Setyawan, 2006). 


\section{HASIL}

Dari data yang diperoleh pada pengujian resistivitas, ditentukan hubungan resistivitas terhadap penambahan massa pasir dan hubungan resistivitas terhadap penambahan massa resin.

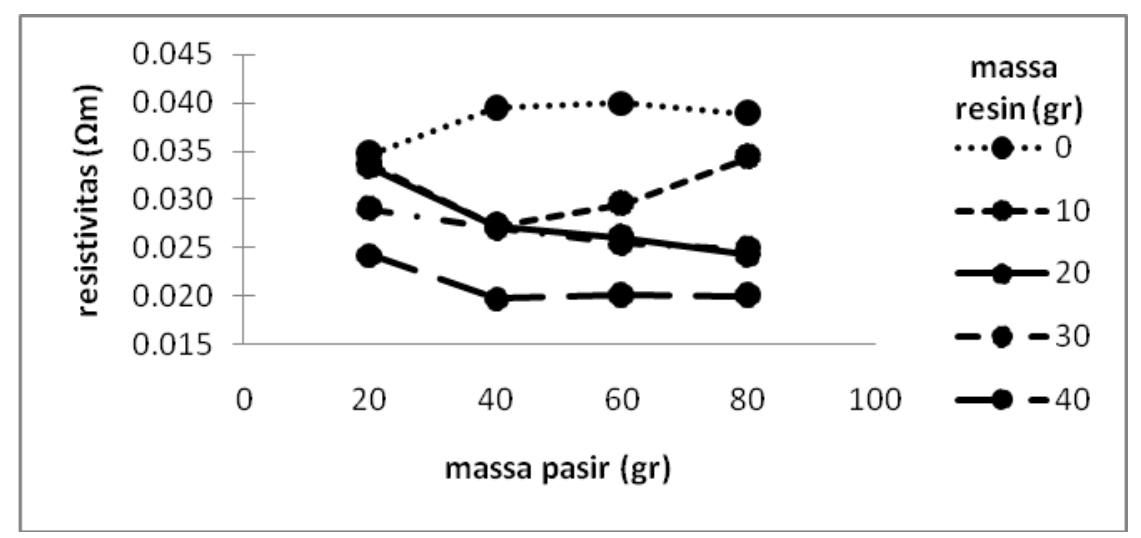

Gambar 1 Grafik hubungan resistivitas dan massa pasir

Berdasarkan Gambar 1, hubungan antara resistivitas terhadap massa pasir untuk berbagai massa resin menunjukkan bahwa nilai resistivitas terkecil yaitu $0,020 \Omega \mathrm{m}$ dihasilkan oleh campuran pasir-semen dengan massa pasir 80 gr pada massa resin 40 gr, sedangkan nilai resistivitas terbesar yaitu $0,040 \Omega \mathrm{m}$ dengan massa pasir 60 gram pada massa resin 0 gr. Penurunan nilai resistivitas yang cukup besar terlihat pada sampel dengan penambahan massa pasir 40 gr, 60 gr, dan 80 gr pada massa resin 20 gr, 30 gr, dan 40 gr. Terjadi perbedaan bentuk pola pada Gambar 1 dimana terlihat resistivitas mengalami kenaikan sebesar $0,004 \Omega \mathrm{m}$ terlihat pada sampel dengan penambahan massa pasir $40 \mathrm{gr}$ dan $60 \mathrm{gr}$ pada massa resin 0 gr dan kenaikan sebesar $0,007 \Omega \mathrm{m}$ dengan penambahan massa pasir 40 gr, 60 gr, dan 80 gr pada massa resin 10 gr. Kenaikan resistivitas yang terjadi (penyimpangan) diperoleh dari pengukuran resistansi dan panjang dari sampel.

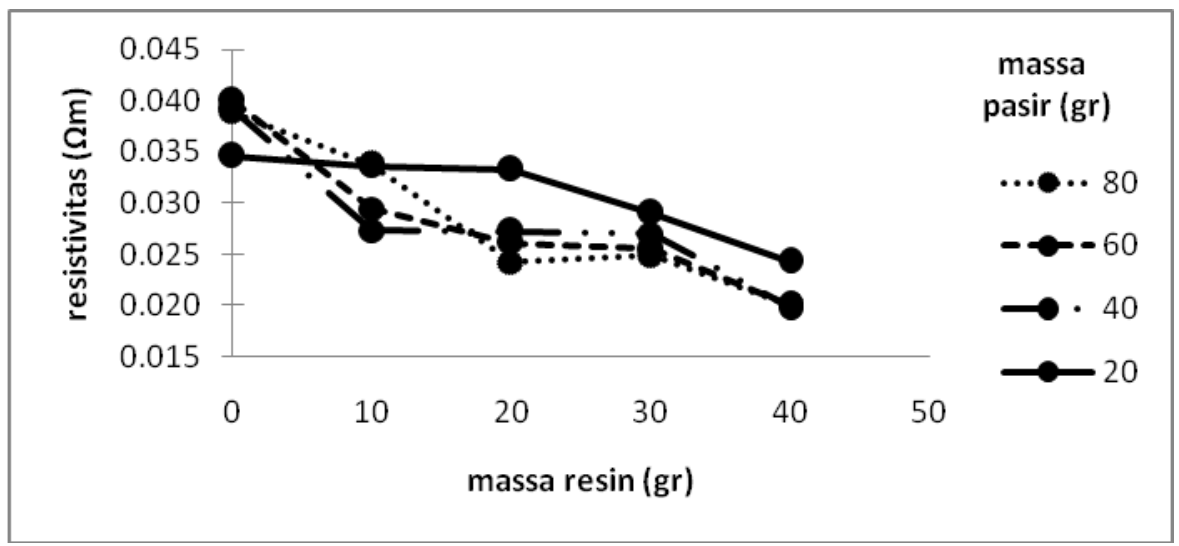

Gambar 2 Grafik hubungan resistivitas dan massa resin

Secara umum, pada Gambar 2, terlihat bahwa nilai resistivitas mengalami penurunan dengan diberikan penambahan massa resin. Penurunan nilai resistivitas terbesar pada massa pasir 40 gr yaitu $0,012 \Omega \mathrm{m}$ dengan penambahan massa resin 10 gr. Dari data pengujian, penambahan massa pasir dan massa resin menurunkan nilai resistivitas campuran pasir-semen. Nilai yang dihasilkan dari hasil pengujian resistivitas campuran pasir-semen berada dalam rentang 0,020-0,040 $\Omega \mathrm{m}$. Hasil ini memperlihatkan nilai yang 
berbeda jauh dengan resistivitas material asalnya, yaitu pasir dengan resistivitas 1-1000 $\Omega \mathrm{m}$ dan resin dengan resistivitas $2-10^{5} \Omega \mathrm{m}$. Faktor penambahan massa pasir dan massa resin dalam pembuatan campuran pasir-semen menghasilkan nilai yang berbeda-beda, seperti sampel dengan massa pasir 80 gr, massa semen 60 gr dan massa resin 0 gr dengan nilai resistivitas $0,039 \Omega \mathrm{m}$, sedangkan pada sampel dengan massa pasir 80 gr, massa semen 60 gr dan massa resin 40 gr, didapatkan nilai resistivitas sebesar 0,020 $\Omega \mathrm{m}$. Dengan bertambahnya massa resin yang diberikan pada campuran pasir-semen, maka nilai resistivitas dari campuran pasir-semen akan semakin kecil. Penurunan nilai resistivitas yang terjadi disebabkan oleh panjang dari sampel campuran pasir-semen, karena setiap diberikan penambahan massa resin, maka panjang dari sampel akan bertambah panjang yang menyebabkan nilai resistivitas semakin kecil, dimana nilai resistivitas berbanding terbalik dengan panjang dari sampel. Jadi semakin panjang sampel maka nilai resistivitasnya akan semakin kecil. Secara umum dari Gambar 1 dan 2, dinyatakan nilai resistivitas semakin menurun dengan semakin bertambahnya massa resin, sedangkan penambahan massa pasir pada bahan tidak memperlihatkan pola yang baik terhadap nilai resistivitas.

Dari data yang diperoleh pada pengujian porositas, ditentukan hubungan porositas terhadap penambahan massa pasir dan hubungan porositas terhadap penambahan massa resin.

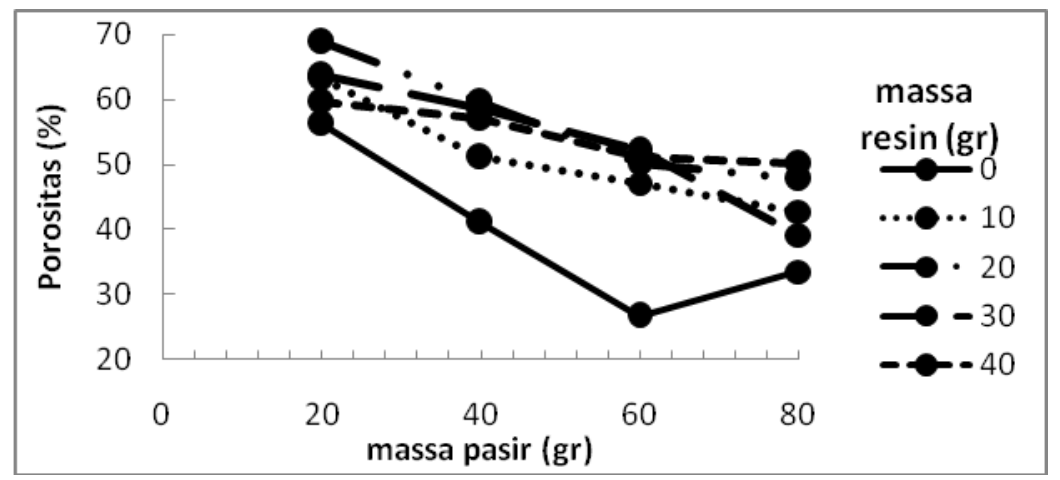

Gambar 3 Grafik hubungan porositas dan massa pasir

Berdasarkan Gambar 3, didapatkan nilai porositas terbesar yaitu $69 \%$ dengan penambahan massa pasir 20 gr pada massa resin 20 gr, sedangkan nilai porositas terkecil sebesar $27 \%$ dengan penambahan massa pasir 60 gr pada massa resin 0 gr. Secara umum nilai porositas campuran pasir-semen turun dengan bertambahnya massa pasir pada campuran pasir-semen. Penurunan nilai porositas terbesar didapatkan pada massa pasir 20-60 gr dengan penurunan nilai porositas sebesar $29 \%$ pada massa resin 0 gr, dan terjadi kenaikan nilai porositas pada sampel dengan massa pasir 80 gr.

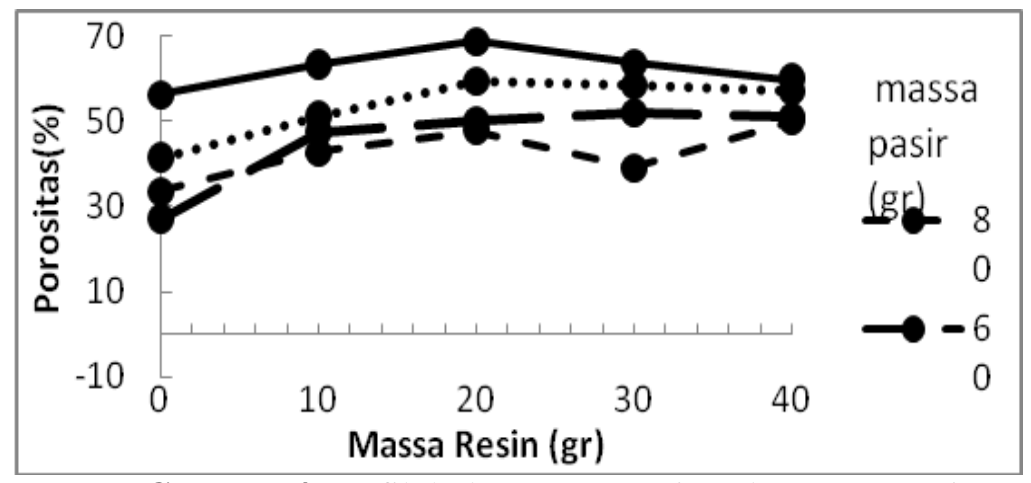

Gambar 4 Grafik hubungan porositas dan massa resin 
Gambar 4 memperlihatkan hubungan antara porositas terhadap massa resin, dimana secara umum terlihat bahwa nilai porositas naik dengan bertambahnya massa resin. Nilai porositas akan naik hingga penambahan massa resin 20 gr dan menurun atau konstan setelah diberikan penambahan massa resin sampai 40 gr. Perbedaan pola hubungan porositas terhadap massa resin terlihat pada sampel dengan massa pasir 80 gr dan massa resin $30 \mathrm{gr}$, dimana terlihat penurunan nilai porositas yang sangat jauh.

Dari data pengujian porositas, penambahan massa pasir dan massa resin menghasilkan nilai porositas semakin kecil dengan bertambahnya massa pasir. Nilai porositas semakin besar dengan penambahan massa resin 0-20 gr dan menurun atau terdapat perbedaan yang kecil dengan penambahan massa resin 20-40 gr. Terjadinya penurunan nilai porositas saat diberi penambahan massa pasir disebabkan oleh pasir mempunyai massa jenis yang lebih berat, ketika dicampur dengan partikel lain pasir lebih mudah mengendap, sehingga membuat pori-pori yang terbentuk lebih kecil. Kenaikan porositas yang terjadi pada saat diberi penambahan massa resin juga disebabkan oleh massa jenis resin yang lebih ringan dan ketika dicampur dengan partikel lain, resin tidak mudah untuk mengendap atau menekan partikel lain yang dicampur, sehingga pori-pori yang terbentuk lebih besar. Tetapi ada perbedaan dengan porositas yang diberi penambahan massa resin lebih dari 20 gr, porositas terlihat menurun yang kemungkinan disebabkan oleh massa resin yang diberikan mulai jenuh dan akhirnya resin mengendap sehingga pori-pori yang terbentuk lebih kecil. Penambahan massa resin yang terlihat pada Gambar 4 memperlihatkan bahwa penambahan massa resin yang bagus (bisa direkomendasikan) adalah pada massa resin 20-40 gr. Karena pada penambahan massa resin tersebut terlihat porositas menurun dengan semakin bertambahnya massa resin.

\section{DAFTAR PUSTAKA}

1. Setyawan, B. M. I.,2006, Pengaruh Penambahan Serbuk Gergaji Kayu Jati (Tectona Grandis L.F) Pada Mortar Semen Ditinjau Dari Kuat Tekan, Kuat Tarik Dan Daya Serap Air, Teknik Sipil, Semarang : Universitas Negeri Semarang.

2. Liu, S.Y., Du, Y.J., Han, L.H., dan Gu, M.F., 2008, Experimental study on the electrical resistivity of soil-cement admixtures, Environmental Geology 54 : 12271233

3. Putra, A., Handayani, G., Satira, S. dan Nugraha, N., 2010, Resistivitas Campuran Semen dan Resin sebagai Bahan Kedap Air, Prosiding Seminar dan Rapat Tahunan BKS-PTN Wilayah Barat ke-23 : 338-341 